Article

\title{
Endogenous Sphingolipid Signaling Pathway Implicated in the Action of Croton membranaceus on the Prostate Gland in BPH Patients
}

\author{
George Awuku Asare 1,*, Yvonne Anang ${ }^{1}$, Daniel K. Afriyie ${ }^{2}$, Brodrick Yeboah Amoah ${ }^{1}$, \\ Bernice Asiedu ${ }^{1}$, Derek Doku ${ }^{1}$, Hannah Serwah Ocansey ${ }^{1}$, Nana Yaw Odei Danso ${ }^{1}$, \\ Prince Tekpor ${ }^{1}$ and Sarah Osam ${ }^{1}$ \\ 1 Chemical Pathology Unit, Department of Medical Laboratory Sciences, School of Biomedical and Allied \\ Health Sciences, College of Health Sciences, University of Ghana, P.O. Box KB 143, Korle-bu, Accra, Ghana; \\ vongh2002@yahoo.co.uk (Y.A.); abybrodrick@yahoo.com (B.Y.A.); benysea2@gmail.com (B.A.); \\ amarteydd@gmail.com (D.D.); ohannahsaige1@yahoo.com (H.S.O.); odynaan@gmail.com (N.Y.O.D); \\ ptekpor@yahoo.com (P.T); sarahosam95@gmail.com (S.O.) \\ 2 Department of Pharmacy, Ghana Police Hospital, Cantonments, Accra, Ghana; dspdan77@yahoo.com \\ * Correspondence: gasare@chs.edu.gh; Tel.: +233-244-627-456
}

Academic Editor: Gerhard Litscher

Received: 1 October 2017; Accepted: 15 November 2017; Published: 18 November 2017

\begin{abstract}
Background: Croton membranaceus extract has apoptotic effects on BPH-1 cells. This study determined if the apoptotic effects were created through the ceramide pathway. Methods: The study was a follow-up to a previous observational study of 30 histologically confirmed patients with benign prostatic hyperplasia (BPH) who were on C. membranaceus ethanolic extract at $20 \mathrm{mg}$ t.i.d orally for 3 mo. Thereafter, total and free prostate-specific antigen (PSA), lipid profile plus Apo lipoprotein A and B, ceramide/Sphingophospho-kinase 1 (SphK1) and 2 (SphK2), sphingosine lyase (SPL), the cytotoxic adducts of oxidative stress 4-hydroxy-2-nonenal (4HNE) and malondialdehyde (MDA), were determined. Results: Total and free PSA were significantly $(p<0.05)$ different after treatment. Apo lipoprotein A was significantly different $(p=0.024)$. The SphK1/SphK2 ratio reduced significantly $(p=0.049)$. Furthermore, SPL, ceramide, and MDA increased significantly after treatment ( $p=0.05, p=0.004$, and $p=0.007$, respectively). A weak positive correlation was found between high-density lipoprotein (HDL) cholesterol and SphK1, and HDL and ceramide before treatment ( $p=0.036, \mathrm{r}=0.3826 ; p=0.018, \mathrm{r}=0.4286$, respectively. Conclusions: $C$. membranaceus uses the ceramide pathway by modulating the SphK1/SphK2 ratio and increasing SPL to generate oxidative stress and consequently apoptosis.
\end{abstract}

Keywords: Ceramide; sphingolipid; prostate; Croton membranaceus

\section{Introduction}

Cell survival or death is regulated by a sphingolipid pathway that results in the growth of tumors [1]. Ceramide, a C18 lipid also known as a tumor suppressor lipid, and sphingosine are pro-apoptotic in nature, whereas the metabolic product sphingosine-1-phosphate (SIP) is pro-proliferative in nature [2]. These sphingolipids play a signaling role in tumorigenesis [3]. Under pathogenic conditions, the conversion of ceramide to SIP is the primary mechanism leading to cell growth and proliferation. Thus, the pro-apoptotic and pro-proliferative sphingolipids are called the sphingolipid rheostat. The ratio of sphingosine or ceramide to SIP is a determinant of cell growth or death [4]. A high ratio favors apoptosis and the reverse favor cell proliferation.

Some studies have shown that ceramide exerts its apoptotic effect using the intrinsic pathway. In response to apoptotic stimuli, ceramide acts on a class of proteins known as Bcl-2 proteins, enhancing 
the activation of pro-apoptotic Bcl-2 proteins and inhibiting anti-apoptotic Bcl-2 proteins [5]. Ceramide also triggers mitochondrial outer membrane permeabilization (MOMP), activates the release of cytochrome $\mathrm{C}$ and other apoptogenic proteins into the cytosol, and initiates the production of reactive oxygen species, which enhance apoptosis [6].

The fate of a cell is also determined by ceramide and ceramide-1-phosphate. Growth inhibition and apoptotic activities occur in the long chain bases as well as in ceramide, where their phosphorlylated metabolites stimulate proliferation and growth. For normal cell function, the modulation of these lipids and their opposing metabolites is therefore essential [7,8]. The catalytic actions of sphingosine kinases on sphingosine biosynthesis result in the production of long-chain bases [9]. Cellular uptake mechanisms result in phosphorylation at position one of these long-chain bases. Furthermore, dephosphorylation is possible through the action of sphingosine-1-phosphate phosphatases or type 2 phosphatidate phosphohydrolases $[10,11]$. On the other hand, sphingosine phosphate lyase (SPL) metabolizes the phosphate intermediates irreversibly into long-chain phosphoethanolamines and aldehydes [12].

Sphingosine kinase has two isoenzymes, sphingosine phosphokinase 1 (SphK1) and sphingosine phosphokinase 2 (SphK2), located in different subcellular compartments [13]. SphK1 is found in the cytosol and transferred into the plasma membrane when stimulated. Cell proliferation has been shown to be enhanced by increased SphK1 expression in cell lines with the promotion of G1-S transition, which was previously protected from apoptosis. However, S1P has been suggested to suppress apoptosis as a result of SphK1 induction not being mediated by S1P receptors [14,15]. An increased SphK1 expression has been observed in solid tumors and in cancers, including breast, colon, rectum, and ovary cancers [16,17].

The combination of SPL-enforced expression with SphK1 may be a silencing strategy that decreases S1P content in the prostate, which may result in increasing the sensitivity of prostate cancer cells to anticancer therapies [18].

On the other hand, SphK2 is said to have a BH3-only motif and functions upon stimuli from the cytosol to the nucleus, promoting apoptosis through the mitochondrial pathway. In several cell lines, SphK2 expression has been associated with the inhibition of DNA synthesis [19]. SphK2 and SphK1 use SIP as a common substrate; however, SphK2-induced apoptosis is independent of the activation of $\mathrm{S} 1 \mathrm{P}$ receptors, but interacts with the anti-apoptotic member Bclx-L [20].

The downregulation of SphK2 reduces the conversion of sphingosine to ceramide in the salvage pathway, whereas downregulation of SphK1 enhances this process, resulting in elevated ceramide levels [21]. Thus, it has been suggested that SphK1 and SphK2 have opposite effects.

In contrast, downregulation of critical oncogenes by a selective SphK2 inhibitor hindered prostate cancer progression [22]. SphK2 has been shown to be capable of promoting proliferation in breast cancer cells [23]. Therefore, the role of these two enzymes is not clearly understood and may vary in different pathological settings.

Several phytotherapeutic agents are purported to have success in the management of benign prostatic hyperplasia (BPH). Two monoherbal plants, Urticadioica L. and Trifolium pretense (red clover), have been shown to reduce BPH [24]. Croton membranaceus was also observed to shrink the prostate in BPH patients, and an in vivo study implicated a possible apoptotic mechanism [25]. However, almost no research has been able to show the exact mechanism by which these plant medicines work in humans. The aim of this study was to determine if the apoptotic nature of the extract of C. membranaceus occurs through the ceramide pathway.

\section{Materials and Methods}

\subsection{Study Design and Site}

The study was a retrospective study, using archival samples from an observational study in patients who opted for C. membranaceus use in the management of their BPH, at the Ghana 
Police Hospital. The Ghana Police Hospital is one of the 11 centers in the country approved by the Ministry of Health to dispense plant medicine to patients who opt for that type of treatment. Blood samples of 30 patients who used the ethanolic root extract of C. membranaceus capsules (20 mg t.i.d.) for a period of 3 months were analyzed. Frozen archival blood samples were selected and analyzed. Before treatment and after treatment samples were used. The characterized phtyochemicals in C. membranaceus were terpenoids, dipeteroids, furano-clerodanediterpeniod, crotomembranafuran, $\quad N[N-(2-m e t h y l b u t a n o y l)$ glutaminoyl-2-phenylethylamine, glutarimide alkaloid, julocrotine, beta-sitosterol, beta-sitosterol-3-D-glucoside, labdanediterpioid, gomojoside $\mathrm{H}$, and DL-thrietol [26].

\subsection{Ethical Issues}

The Ethics and Protocol Review Committee of the School of Biomedical and Allied Health Sciences granted approval for the study with ethics number SAHS-ET/SAHS/PSM/ML/09/AA/26A/2012-2013. The Ghana Police Hospital administration granted approval for the study to be undertaken at the facility. Participants whose data and samples were used provided informed consent. The study complied with the Helsinki Declaration of 1964, with revision in October 2008.

\subsection{Methods}

Biochemical assays, including total and free prostate specific antigen (TPSA and FPSA), were performed using AccuBind total and free PSA ELISA kits purchased from MonoBind Inc. (Lake Forest, CA, USA). The ELISA plate was coated with highly specific mono-clonal anti-PSA antibodies, and assays were performed according to the manufacturer's instructions.

The lipid profile, including total cholesterol (TC), triglycerides (TG), high density lipoprotein (HDL), low density (LDL) apolioprotein A-1 (Apo A), and apolioprotein B (Apo B), were determined using BioSystem A25 (Madrid, Spain) with BioSystems reagents.

Sphingosine phosphokinase 1 and 2 ELISA kits were purchased from MyBiosource (San Diego, CA, USA). Ceramide, sphingosine-1-phospahe lyase and malondialdehyde (MDA) ELISA kits were purchased from Sunlong Biotech Co. Ltd. (Hangzhou, China). All tests were performed using assay protocols as directed by the manufacturers.

\subsection{Statistical Analysis}

IBM SPSS statistics for Windows, Version 21.0 (IBM Corporation, Armonk, NY, USA) and Microsoft Excel 2013 were used for the statistical analysis. Data are presented as mean \pm standard deviation. Statistical analysis between groups was determined by student's $t$-test. Correlation analysis was performed with Pearson correlation test. The level of significance was $p<0.050$.

\section{Results}

Significant reductions were seen in total PSA (TPSA) and free PSA (TPSA) $(p=0.000$ and $p=0.018$, respectively) at the end of the treatment period (Table 1). From Table 2, a significant increase was observed in Apo A-1 after treatment $(p=0.024)$. Although SphK1 and SphK2 were lowered after treatment, differences were not significant. However, the SphK1:SphK2 ratios decreased significantly after treatment $(p=0.049)$. On the contrary, SPL increased significantly after treatment $(p=0.05)$ (Table 3). Ceramide increased from $64.77 \pm 11.09$ to $72.92 \pm 10.83 \mathrm{ng} / \mathrm{mL}$. The increase was highly significant $(p=0.004)$ (Table 4). Positive correlations were observed between HDL before treatment for SphK1 and ceramide $(\mathrm{r}=0.382, p=0.036$; and $\mathrm{r}=0.428, p=0.018$, respectively) (Table 5$)$, and between TG and SPL ( $p=0.015, \mathrm{r}=0.4370$ ) before treatment (Table 6$)$. 
Table 1. Parameters relating total PSA (TPSA) and free PSA (FPSA) shown as mean values before and after treatment.

\begin{tabular}{cccc}
\hline Parameter $(\mathbf{n g} / \mathrm{mL})$ & Mean \pm SD Before & Mean \pm SD After & $p$-Value Before/After \\
\hline TPSA & $25.71 \pm 20.10$ & $16.15 \pm 15.66$ & $0.000^{*}$ \\
FPSA & $4.54 \pm 3.17$ & $3.25 \pm 2.57$ & $0.018^{*}$ \\
\hline
\end{tabular}

* Signifies $p<0.05$.

Table 2. Lipid profile including total cholesterol (TC), triglyceride (TG), high and low density lipoprotein (HDL, LDL), and Apolioprotein A-1 (APO A) and B, before and after treatment.

\begin{tabular}{cccc}
\hline Parameter $(\mathbf{m m o l} / \mathbf{L})$ & Mean \pm SD Before & Mean \pm SD After & $\boldsymbol{p}$-Value Before/After \\
\hline TC & $5.03 \pm 1.12$ & $5.19 \pm 1.15$ & 0.423 \\
TG & $1.15 \pm 0.43$ & $1.22 \pm 0.56$ & 0.517 \\
HDL & $0.76 \pm 0.33$ & $0.88 \pm 0.32$ & 0.062 \\
LDL & $3.74 \pm 1.03$ & $3.75 \pm 1.02$ & 0.959 \\
AP0 A & $1.31 \pm 0.45$ & $1.52 \pm 0.47$ & $0.024^{*}$ \\
APO B & $0.58 \pm 0.37$ & $0.50 \pm 0.13$ & 0.2221 \\
\hline
\end{tabular}

* Signifies $p<0.05$.

Table 3. Mean values of sphingosine phosphokinase 1 and 2 (SphK1 and SphK2) and their ratios, as well as sphingosine phosphate lyase (SPL), before and after treatment.

\begin{tabular}{cccc}
\hline Parameter $(\mathbf{n g} / \mathbf{m L})$ & Mean \pm SD Before & Mean \pm SD After & $p$-Value Before/After \\
\hline SPK 1 & $1.84 \pm 1.34$ & $1.50 \pm 1.29$ & 0.302 \\
SPK 2 & $110.4 \pm 57.67$ & $98.63 \pm 34.59$ & 0.359 \\
SPK1 /SPK2 & $0.042 \pm 0.018$ & $0.017 \pm 0.011$ & $0.049 *$ \\
SPK Lyase & $143.7 \pm 24.20$ & $161.4 \pm 35.66$ & $0.050 *$ \\
\hline
\end{tabular}

* Signifies $p<0.05$.

Table 4. Mean ceramide levels before and after treatment.

\begin{tabular}{cccc}
\hline Parameter $(\mathbf{n g} / \mathrm{mL})$ & Mean \pm SD Before & Mean \pm SD After & $p$-Value Before/After \\
\hline Ceramide & $64.77 \pm 11.09$ & $72.92 \pm 10.83$ & $0.004^{*}$ \\
MDA & $41.15=16.00$ & $52.95=15.18$ & $0.047^{*}$ \\
\hline
\end{tabular}

* Signifies $p<0.05$.

Table 5. A correlation between HDL and the individual analyses.

\begin{tabular}{ccccc}
\hline Parameter & r-Value Before & r-Value After & $p$-Value Before & $p$-Value After \\
\hline TPSA (ng/mL) & -0.0741 & 0.2372 & 0.697 & 0.206 \\
APO A (mmol/L) & 0.2045 & -0.2338 & 0.278 & 0.213 \\
SPK2 $(\mathrm{ng} / \mathrm{mL})$ & 0.0827 & 0.0936 & 0.664 & 0.622 \\
SPK1 $(\mathrm{ng} / \mathrm{mL})$ & 0.3826 & -0.1649 & $0.036^{*}$ & 0.383 \\
SPK Lyase $(\mathrm{ng} / \mathrm{mL})$ & 0.0324 & -0.2275 & 0.864 & 0.226 \\
Ceramide $(\mathrm{ng} / \mathrm{mL})$ & 0.4286 & 0.0227 & $0.018^{*}$ & 0.905 \\
\hline \multicolumn{5}{c}{ * Signifies $p<0.05}$.
\end{tabular}

* Signifies $p<0.05$.

Table 6. Correlation between SP-Lyase and lipids.

\begin{tabular}{ccccc}
\hline Parameter $(\mathbf{m m o l} / \mathbf{L})$ & r-Value Before & r-Value After & $\boldsymbol{p}$-Value Before & $\boldsymbol{p}$-Value After \\
\hline T. Chol & -0.1181 & 0.0634 & 0.5343 & 0.7393 \\
TG & 0.4370 & 0.0329 & $0.0158^{*}$ & 0.8628 \\
HDL & 0.0324 & -0.2275 & 0.8649 & 0.2266 \\
LDL & -0.2229 & 0.1330 & 0.2365 & 0.4834 \\
\hline
\end{tabular}

* Signifies $p<0.05$. 


\section{Discussion}

The use of medicinal plants for various conditions is increasing globally. For 70-80\% of most populations, these plants are most readily available and affordable. However, even in settings where allopathic medicine is widely available, some people have a deliberate preference for medicinal plants because they are thought to be natural and safe. In Italy, 50\% of the BPH medications are phytotherapies, and in some European countries, first-line BPH treatment involves the use of phytotherapies [27].

A meta-analysis by Azimi et al. [24] revealed that, although many medicinal plants have been suggested to manage BPH given the results of in vitro experiments, few have demonstrated the same effects in vivo. Furthermore, the few in vivo experiments have not surpassed a few clinical markers, such as International Prostate Symptoms Score (IPSS) and Lower Urinary Tract Symptoms (LUTS). Additionally, a great dearth of information exists about the availability of the exact mechanism of action of the few that have been shown to be clinically successful.

Croton membranaceus has been used in Ghana over the past four decades for the management of $\mathrm{BPH}$ and has been shown to shrink the prostate in animal and human experiments [28,29]. Some pathways have been suggested for its action, including the dihydrotestosterone (DHT) reduction by the 5 - $\alpha$-dehydrogenase hormonal pathway, and possible antioxidant activities [30]. In vitro experiments have demonstrated that the aqueous plant extract is cytotoxic and genotoxic [31]. Another experiment at the molecular level showed that the antiproliferative effect on BPH-1 cells was due to a mitochondrion-dependent pathway leading to apoptosis [25]. Although the apoptotic mechanism has been accepted as a mode of action for the plant extract, the exact pathway has not been determined. In this study, a more convincing pathway is presented based on analysis of human serum samples obtained from a previous observational study.

The involvement of lipid metabolism in the pathogenesis of BPH has been demonstrated [32,33]. Metabolic syndrome (MetS) has been implicated in the etiology of BPH. In a related study, the frequent co-existence of MetS and BPH was confirmed [34]. This association seems to be a consequence of the MetS-related metabolic derangements, reduced sex hormone binding globulin (SHBG) levels, and changes in the sex hormones. In that study, the strongest significant predictor of BPH was metabolic syndrome. HDL was negatively correlated with inflammatory infiltrate grade and glandular disruption. Furthermore, after prostatectomy, prostate specimen weight was negatively correlated with HDL levels. Receiver operating characteristic (ROC) curves showed that inflammatory infiltrate grade, extent, and the presence of glandular disruption predicted reduced HDL-cholesterol with an accuracy of $67.4 \%, 72.4 \%$, and $70.2 \%$, respectively [35].

HDL has been found to be lower in BPH patients [36]. BPH has been suggested as a new metabolic disease in aging men that is correlated with sexual dysfunction [37]. In our previous study, sexual function slightly appreciated after treatment with C. membranaceus in tandem with a significant improvement in the quality of life (QoL). In another study, terazosin, an $\alpha-1$ blocker, reduced cholesterol levels in BPH patients with high cholesterol values, while increasing HDL levels [38]. Long-term dutasteride therapy resulted in increased LDL levels [39]. Our previous experiments implicated an increase in lipids, such as HDL, after treatment with C. membranaceus. Additionally, Apo A was significantly reduced. Therefore, this appears to be the only study that has reported HDL reduction in $\mathrm{BPH}$ patients with phytotherapy.

In the literature, the roles of SphK1 and SphK2 remain controversial. Generally, SphK1 is thought to be pro-proliferative and SphK2 is pro-apoptotic. However, some studies have proposed the reverse. The levels of the individual sphingokinases did not show significant differences before and after treatment in this study, although a slight reduction of both occurred after treatment. The ratios of SphK1/SphK2 decreased significantly after treatment, signifying a greater drop in SphK1 compared to SphK2, and thus suggesting the dominance of SphK2 activity over that of SphK1. An increase in SphK1 appears to promote resistance in PCa chemotherapy [40]. We therefore postulate that the ratio of the two is a determining factor for the positive or negative growth of the prostate. 
Reduced expression of SPL apparently favors cell growth. Silencing SphK1 expression in combination with increased SPL expression has been shown to decrease SIP content in prostate cancer cells, thus making them more sensitive to anticancer treatment. This combined strategy could be the future direction of cancer treatment [18].

Conversely, SPL increased significantly in this study. SPL is known for dephosphorilation of sphingosine-1-phosphate (SIP) and ceramide-1-phosphat, altering the rhostate balance toward apoptosis. Therefore, the increase in SPL after treatment signifies increased apoptosis, which aligns with previous in vitro and in vivo studies. SPL is the sole enzyme that irreversibly decreases the amount of intracellular SIP, by cleaving it into hexadecenal and ethanolamine phosphate, as the last steps in the sphingomyelin degradation pathway [41]. Other studies have demonstrated that an increase in SPL expression results from stress, irradiation [42], and chemotherapy [43,44] using non-cancerous cells.

The significant increase in ceramide obtained comparing before and after treatment values $(p=0.004)$ is the most convincing among the possible suggested pathways, meaning the ceramide pathway is involved in the phytotherapeutic action of $C$. membranaceus. Increasing the cytotoxic response to chemotherapy in prostate cells by increasing intracellular ceramide concentration may be worthwhile [45].

The degradation of ceramide involves ceramidases. The inhibition of ceramidase was thought to be a possible mechanism for increasing ceramide levels. A study using B13, an inhibitor of acid ceramidase, on human prostate cancer cell lines and xenografts showed that B13 produced tumors, and microscopic evaluation of the tumors demonstrated the presence of apoptosis [46]. In this study, the importance of the increase found in ceramide is corroborated by findings observed in other studies demonstrating that intracellular ceramide increases alone, and not a balance between SIP and ceramide, determines whether apoptosis will occur in LNCaP cells [47]. Furthermore, a strong correlation was observed in apoptosis, induced by serum deprivation in androgen-independent prostate cancer cell lines and ceramide in that study.

\section{Conclusions}

We conclude that $C$. membranaceus uses the ceramide pathway by modulating the SphK1/SphK2 ratio and the increase of SPL to generate oxidative stress, significantly increasing MDA, which supports the previously proven apoptotic effect, and PSA reduction activity, of the extract.

Author Contributions: G.A.A. conceptualized the study; H.S.O., N.Y.O.D., P.T., S.O. performed the assays; Y.A., B.A., D.D. performed statistical analysis; G.A.A., D.K.A., B.Y.A. wrote the manuscript.

Conflicts of Interest: Authors declare there is no conflict of interest.

\section{References}

1. Chapman, J.V.; Gouazé-Andersson, V.; Messner, M.C.; Flowers, M.; Karimi, R.; Kester, M.; Barth, B.M.; Liu, X.; Liu, Y.Y.; Giuliano, A.E.; et al. Metabolism of short-chain ceramide by human cancer cells-Implications for therapeutic approaches. Biochem. Pharmacol. 2010, 80, 308-315. [CrossRef] [PubMed]

2. Brizuela, L.; Martin, C.; Jeannot, P.; Ader, I.; Gstalder, C.; Andrieu, G.; Bocquet, M.; Laffosse, J.M.; Gomez-Brouchet, A.; Malavaud, B.; et al. Osteoblast-derived sphingosine 1-phosphate to induce proliferation and confer resistance to therapeutics to bone metastasis-derived prostate cancer cells. Mol. Oncol. 2014, 8, 1181-1195. [CrossRef] [PubMed]

3. Lin, H.M.; Mahon, K.L.; Weir, J.M.; Mundra, P.A.; Spielman, C.; Briscoe, K.; Gurney, H.; Mallesara, G.; Marx, G.; Stockler, M.R.; et al. A distinct plasma lipid signature associated with poor prognosis in castration-resistant prostate cancer. Int. J. Cancer 2017. [CrossRef] [PubMed]

4. Pyne, N.J.; Pyne, S. Sphingosine 1-phosphate and cancer. Nat. Rev. Cancer 2010, 10, 489-503. [CrossRef] [PubMed]

5. Ueda, N. Ceramide-induced apoptosis in renal tubular cells: A role of mitochondria and sphingosine-1phoshate. Int. J. Mol. Sci. 2015, 16, 5076-5124. [CrossRef] [PubMed] 
6. Colombini, M. Ceramide channels and their role in mitochondria-mediated apoptosis. Biochim. Biophys. Acta 2010, 1797, 1239-1244. [CrossRef] [PubMed]

7. Hannun, Y.A.; Luberto, C.; Argraves, K.M. Enzymes of sphingolipid metabolism: From modular to integrative signaling. Biochemistry 2001, 40, 4893-4903. [CrossRef] [PubMed]

8. Gómez-Muñoz, A.; Kong, J.; Parhar, K.; Wang, S.; Gangoiti, P.; González, M.; Eivemark, S.; Salh, B.; Duronio, V.; Steinbrecher, U. Ceramide-1-phosphate promotes cell survival through activation of the phosphatidylinositol 3-kinase/protein kinase B pathway. FEBS Lett. 2005, 579, 3744-3750. [CrossRef] [PubMed]

9. Liu, H.; Sugiura, M.; Nava, V.E.; Edsall, L.C.; Kono, K.; Poulton, S.; Milstien, S.; Kohama, T.; Spiegel, S. Molecular cloning and functional characterization of a novel mammalian sphingosine kinase type 2 isoform. J. Biol. Chem. 2000, 275, 19513-19520. [CrossRef] [PubMed]

10. Mandala, S.M.; Thornton, R.; Galve-Roperh, I.; Poulton, S.; Peterson, C.; Olivera, A.; Bergstrom, J.; Kurtz, M.B.; Spiegel, S. Molecular cloning and characterization of a lipid phosphohydrolase that degrades sphingosine-1-phosphate and induces cell death. Proc. Natl. Acad. Sci. USA 2000, 97, 7859-7864. [CrossRef] [PubMed]

11. Le Stunff, H.; Peterson, C.; Liu, H.; Milstien, S. Sphingosine-1-phosphate and lipid phosphohydrolases. Biochim. Biophys. Acta 2002, 1582, 8-17. [CrossRef]

12. Van Veldhoven, P.P.; Mannaerts, G.P. Sphingosine-phosphate lyase. Adv. Lipid Res. 1993, 26, 69-98. [PubMed]

13. Neubauer, H.A.; Pitson, S.M. Roles, regulation and inhibitors of sphingosine kinase 2. FEBS J. 2013, 280, 5317-5336. [CrossRef] [PubMed]

14. Olivera, A.; Rosenfeldt, H.M.; Bektas, M.; Wang, F.; Ishii, I.; Chun, J.; Milstien, S.; Spiegel, S. Sphingosine kinase type 1 induces G12/13 mediated stress fiber formation, yet promotes growth and survival independent of G protein-coupled receptors. J. Biol. Chem. 2003, 278, 46452-46460. [CrossRef] [PubMed]

15. Hait, N.C.; Oskeritziana, C.A.; Paugha, S.W.; Milstienb, S.; Spiegela, S. Sphingosine kinases, sphingosine 1-phosphate, apoptosis and diseases. Biochim. Biophys. Acta 2006, 1758, 2016-2026. [CrossRef] [PubMed]

16. Alshaker, H.; Sauer, L.; Monteil, D.; Ottaviani, S.; Srivats, S.; Böhler, T.; Pchejetski, D. Therapeutic Potential of Targeting SK1 in Human Cancers. Adv. Cancer Res. 2013, 117, 143-200. [PubMed]

17. Heffernan-Stroud, L.A.; Helke, K.L.; Jenkins, R.W.; De Costa, A.M.; Hannun, Y.A.; Obeid, L.M. Defining a role for sphingosine kinase 1 in p53-dependent tumors. Oncogene 2012, 31, 1166-1175. [CrossRef] [PubMed]

18. Brizuela, L.; Ader, I.; Mazerolles, C.; Bocquet, M.; Malavaud, B.; Cuvillier, O. First evidence of sphingosine 1-phosphate lyase protein expression and activity downregulation in human neoplasm: Implication for resistance to therapeutics in prostate cancer. Mol. Cancer Ther. 2012, 11, 1841-1851. [CrossRef] [PubMed]

19. Igarashi, N.; Okada, T.; Hayashi, S.; Fujita, T.; Jahangeer, S.; Nakamur, S. Sphingosine kinase 2 is a nuclear protein and inhibits DNA synthesis. J. Biol. Chem. 2003, 278, 46832-46839. [CrossRef] [PubMed]

20. Strub, G.M.; Maceyka, M.; Hait, N.C.; Milstien, S.; Spiegela, S. Extracellular and Intracellular Actions of Sphingosine-1-Phosphate. Adv. Exp. Med. Biol. 2010, 688, 141-155. [PubMed]

21. Maceyka, M.; Sankala, H.; Hait, N.C.; Le Stunff, H.; Liu, H.; Toman, R.; Collier, C.; Zhang, M.; Satin, L.S.; Merrill, A.H., Jr.; et al. SphK1 and SphK2, sphingosine kinase isoenzymes with opposing functions in sphingolipid metabolism. J. Biol. Chem. 2005, 280, 37118-37129. [CrossRef] [PubMed]

22. Schrecengost, R.S.; Keller, S.N.; Schiewer, M.J.; Knudsen, K.E.; Smith, C.D. Downregulation of Critical Oncogenes by the Selective SK2 Inhibitor ABC294640 Hinders Prostate Cancer Progression. Mol. Cancer Res. 2015. [CrossRef] [PubMed]

23. Antoon, J.W.; White, M.D.; Slaughter, E.M.; Driver, J.L.; Khalili, H.S.; Elliott, S.; Smith, C.D.; Burow, M.E.; Beckman, B.S. Targeting NFkB mediated breast cancer chemoresistance through selective inhibition of sphingosine kinase-2. Cancer Biol. Ther. 2011, 11, 678-689. [CrossRef] [PubMed]

24. Azimi, H.; Khakshur, A.A.; Aghdasi, I.; Fallah-Tafti, M.; Abdollahi, M. A review of animal and human studies for management of benign prostatic hyperplasia with natural products: Perspective of new pharmacological agents. Inflamm. Allergy Drug Targets 2012, 11, 207-221. [CrossRef] [PubMed]

25. Afriyie, D.K.; Asare, G.A.; Bugyei, K.; Lin, J.; Peng, J.; Hong, Z. Mitochondria-dependent apoptogenic activity of aqueous root extract of Croton membranaceus against human BPH-1 cells. Genet. Mol. Res. 2014, 1, 149-162. [CrossRef] [PubMed] 
26. Bayor, M. The Anticancer and Other Bioactivity Investigations on the Extract and Some Compounds of Croton membranaceus (Euphobiaceae). Ph.D Thesis, Kwame Nkrumah University of Science and Technology, Kumasi, Ghana, 2008.

27. Nickel, J.C.; Shoskes, D.; Roehrborn, C.G.; Moyad, M. Nutraceuticals in Prostate Disease: The Urologist's Role. Rev. Urol. 2008, 10, 192-206.

28. Afriyie, D.K.; Asare, G.A.; Bugyei, K.; Lin, J.-M.; Peng, J.; Hong, Z.-F. Treatment of benign prostatic hyperplasia with Croton membranaceus in an experimental animal model. J. Ethnopharmacol. 2014, 157, 90-98. [CrossRef] [PubMed]

29. Asare, G.A.; Afriyie, D.; Ngala, R.A.; Annan, Y.; Appiah, A.A.; Musah, I.; Adjei, S.; Bamfo, K.B.; Sule, S.D.; Gyan, B.A.; et al. Shrinkage of Prostate and Improved Quality of Life: Management of BPH Patients with Croton membranaceus Ethanolic Root Extract. Evid.-Based Complement. Altern. Med. 2015. [CrossRef] [PubMed]

30. Appiah, A.A.; Asomaning, W.A.; Oppong, I.V.; Duker-Eshun, G.; Clement, J.A.; Okine, L.K.; Achel, G.; Gyampo, O.; Adjei, S.; Nyarko, A.K.; et al. Prospects of Croton membranaceus for prostate health. In African Natural Plant Products: Volume II: Discoveries and Challenges in Chemistry, Health, and Nutrition; Juliani, H.R., Simon, J.E., Ho, C.-T., Eds.; Oxford University Press: Washington, DC, USA, 2013; Volume 1127, pp. $79-92$.

31. Asare, G.A.; Yahaya, E.S.; Afriyie, D.K.; Adjei, S.; Asiedu, B. Genotoxic and Cytotoxic Activity of Aqueous Extracts of Croton membranaceus in Rodent Bone Marrow and Human Benign Prostate Hyperplasic Cells. EJMP 2015, 9, 1-7. [CrossRef]

32. Parsons, J.K.; Bergstrom, J.; Barrett-Connor, E. Lipids, Lipoproteins, and Risk of Benign Prostatic Hyperplasia in Community Dwelling Men. BJU Int. 2008, 101, 313-318. [CrossRef] [PubMed]

33. Bin, K.L. Epidemiology of clinical benign prostatic hyperplasia. Asian J. Urol. 2017, 4, 148-151.

34. Wang, J.-Y.; Fu, Y.-Y.; Kang, D.-Y. A Systematic Review and Meta-Analysis. The Association between Metabolic Syndrome and Characteristics of Benign Prostatic Hyperplasia. Medicine (Baltimore) 2016, 95, e3243. [CrossRef] [PubMed]

35. Gacci, M.; Santi, R.; Nesi, G.; Giannessi, C.; Sebastianelli, A.; Giancane, S.; Khorrami, S.; Salvi, M.; Vignozzi, L.; Morelli, A. High density lipoprotein (HDL) serum levels are correlated to histologic features of inflammatory infiltrate and weight of prostatic adenoma in men treated with simple prostatectomy for benign prostatic hyperplasia. J. Urol. 2012, 187, e699. [CrossRef]

36. Rył, A.; Rotter, I.; Miazgowski, T.; Słojewski, M.; Dołegowska, B.; Lubkowska, A.; Laszczyńska, M. Metabolic syndrome and benign prostatic hyperplasia: Association or coincidence? Diabetol. Metab. Syndr. 2015, 7, 94. [CrossRef] [PubMed]

37. Corona, G.; Vignozzi, L.; Rastrelli, G.; Lotti, F.; Cipriani, S.; Maggi, M. Benign Prostatic Hyperplasia: A New Metabolic Disease of the Aging Male and Its Correlation with Sexual Dysfunctions. Int. J. Endocrinol. 2014. [CrossRef] [PubMed]

38. Akbay, E.; Bozlu, M.; Doruk, E.; Akbay, E.; Çayan, S.; Ulusoy, E. Effect of Terazosin on the Lipid Profile in Patients with Symptomatic Benign Prostatic Hyperplasia. Urol. Int. 2001, 67, 156-159. [CrossRef] [PubMed]

39. Traish, A.; Haider, K.S.; Doros, G.; Haider, A. Long-term dutasteride therapy in men with benign prostatic hyperplasia alters glucose and lipid profiles and increases severity of erectile dysfunction. Horm. Mol. Biol. Clin. Investig. 2017, 30. [CrossRef] [PubMed]

40. Gao, Y.; Gao, F.; Chen, K.; Tian, M.-I.; Zhao, D.-I. Sphingosine kinase 1 as an anticancer therapeutic target. Drug Des. Dev. Ther. 2015, 9, 3239-3245. [CrossRef] [PubMed]

41. Van Veldhoven, P.P.; Gijsbers, S.; Mannaerts, G.P.; Vermeesch, J.R.; Brys, V. Human sphingosine-1-phosphate lyase: cDNA cloning, functional expression studies and mapping to chromosome 10q22. Biochim. Biophys. Acta 2000, 1487, 128-134. [CrossRef]

42. Kumar, A.; Oskouian, B.; Fyrst, H.; Zhang, M.; Paris, F.; Saba, J.D. S1P lyase regulates DNA damage responses through a novel sphingolipid feedback mechanism. Cell Death Dis. 2011, 2, e11. [CrossRef] [PubMed]

43. Min, J.; Van Veldhoven, P.P.; Zhang, L.; Hanigan, M.H.; Alexander, H.; Alexander, S. Sphingosine-1-phosphate lyase regulates sensitivity of human cells to select chemotherapy drugs in a p38-dependent manner. Mol. Cancer Res. 2005, 3, 287-296. [CrossRef] [PubMed]

44. Oskouian, B.; Sooriyakumaran, P.; Borowsky, A.D.; Crans, A.; Dillard, T.L.; Tam, Y.Y.; Bandhuvula, P.; Saba, J.D. Sphingosine-1-phosphate lyase potentiates apoptosis via p53- and p38-dependent pathways and is down-regulated in colon cancer. Proc. Natl. Acad. Sci. USA 2006, 103, 17384-17389. [CrossRef] [PubMed] 
45. Wang, H.; Charles, A.G.; Frankel, A.J.; Cabot, M.C. Increasing intracellular ceramide: An approach that enhances the cytotoxic response in prostate cancer cells. Urology 2003, 61, 1047-1052. [CrossRef]

46. Samsel, L.; Zaidel, G.; Drumgoole, H.M.; Jelovac, D.; Drachenberg, C.; Rhee, J.G.; Brodie, A.M.H.; Bielawska, A.; Smyth, M.J. The Ceramide Analog, B13, Induces Apoptosis in Prostate Cancer Cell Lines and Inhibits Tumor Growth in Prostate Cancer Xenografts. Prostate 2004, 58, 382-393. [CrossRef] [PubMed]

47. Eto, M.; Bennouna, J.; Hunter, O.C.; Lotze, M.T.; Amoscato, A.A. Importance of C16 ceramide accumulation during apoptosis in prostate cancer cells. Int. J. Urol. 2006, 13, 148-156. [CrossRef] [PubMed]

C 2017 by the authors. Licensee MDPI, Basel, Switzerland. This article is an open access article distributed under the terms and conditions of the Creative Commons Attribution (CC BY) license (http:/ / creativecommons.org/licenses/by/4.0/). 